\title{
Blood lipids in middle-aged British men
}

\author{
D S THELLE,^ A G SHAPER, T P WHITEHEAD, D G BULLOCK, DEBORAH ASHBY, \\ ILA PATEL \\ From the Departments of Clinical Epidemiology and General Practice, Royal Free Hospital School of Medicine, \\ London, and the Department of Clinical Chemistry, Wolfson Research Laboratories, Queen Elizabeth Medical \\ Centre, Birmingham
}

SUMmaRY The concentrations of serum total cholesterol, high density lipoprotein-cholesterol, and triglycerides have been measured in 7735 men aged 40 to 59 years who were drawn from general practices in 24 towns in England, Wales, and Scotland. The distribution of these blood lipids, their interrelations and their association with age, social class, body mass index, cigarette smoking, alcohol intake, and physical activity at work have been examined. Body mass index emerges as the factor most strongly associated with these three blood lipids. Serum total cholesterol increased with increasing body mass index until about $28 \mathrm{~kg} / \mathrm{m}^{2}$ but thereafter showed no further rise. The relation between body mass index and high density lipoprotein-cholesterol was negative and linear; that between body mass index and triglycerides was positive and linear. The inverse relation between high density lipoprotein-cholesterol and triglycerides was independent of the fact that both were related to body mass index. Alcohol intake was associated with increased high density lipoproteincholesterol concentrations and cigarette smoking with lowered high density lipoprotein concentrations; the association with alcohol appeared to be dominant. No significant trends with age were observed for the three blood lipids. In this population, body mass index is closely associated with the concentration of blood lipids but its effects are probably indirect and mediated by a complex of dietary and other factors.

The Regional Heart Study seeks to explain the striking geographical variations in cardiovascular mortality in Great Britain and to define risk factors for cardiovascular disease. The study includes a clinical survey of middle-aged men drawn from general practices in 24 towns in England, Wales, and Scotland, and this paper describes the distribution, determinants, and interrelations of serum lipids in these men.

There is a strong relation between serum lipids and the development of atherosclerosis and coronary heart disease, and both total cholesterol and high density lipoprotein-cholesterol have been firmly established as risk indicators in individuals and in communities. ${ }^{12}$ In the Regional Heart Study, the contribution made by the various serum lipids to the risk of coronary heart disease will be determined in relation to both the prevalence of coronary heart disease at the initial

« Present address: Institute of Community Medicine, University of Tromsø, N-9010 Asgard sykehus, Norway.

Accepted for publication 30 November 1982 screening and to the incidence in the following years. In this descriptive study, however, we are primarily concerned with the overall patterns of serum lipids and their interrelations, and with an examination of the factors affecting these levels in individuals.

\section{Subjects and methods}

The Regional Heart Study includes 7735 men aged 40 to 59 randomly selected from the age-sex registers of representative general practices in 24 towns. The criteria for selecting the towns, the general practices, and the subjects as well as the methods of data collection have been presented in a separate report. ${ }^{3}$

In brief, the 24 towns were primarily selected from those with populations of 50000 to 100000 (1971 census). They were chosen to represent the full range of cardiovascular disease mortality and included towns in all major standard regions. The general practice selected in each town was required to have a social class distribution that reflected the social class distribution of the men of that town. Trained research 205 
nurses administered to each man an extensive standard questionnaire which included questions on smoking habits, alcohol consumption, and occupational history. Body mass index was defined as weight/height ${ }^{2}$. Smoking habits were recorded as follows: never smoked, ex-cigarette smoker, pipe/cigar only, pipe/cigar smokers who were ex-cigarette smokers, and current cigarette smokers at four levels ( 1 to $19,20,21$ to $39, \geqslant 40 /$ day). Alcohol consumption was recorded using questions on frequency, quantity, and type similar to those used in the General Household Survey. Eight drinking categories were used: nondrinkers, drinking on special occasions or 1 to 2 per month, drinking at weekends ( 1 to 2,3 to 6 , or $>6$ drinks per day), and drinking daily or on most days ( 1 to 2,3 to 6 , or $>6$ drinks per day). A "drink" was defined as half a pint of beer, a glass of wine, or a tot of spirits. Those men drinking more than six drinks at weekends or daily will be referred to as weekend or daily heavy drinkers. To determine social class the longest held occupation of each man was coded and the men were then classified within one of the six social classes of the Office of Population Censuses and Surveys. ${ }^{4}$ Each man's information on occupation was used to assess his physical activity at work, employing a simple three-category system. ${ }^{5}$

All the blood samples were obtained in the nonfasting state between 0830 and 1830 hours. No adjustments have been made for the diurnal variations in serum triglyceride and high density lipoproteincholesterol (HDL-cholesterol) concentrations; the implications of this will be discussed in the presentation of the findings. The estimations of serum total cholesterol and high density lipoprotein cholesterol were carried out in the Wolfson Research Laboratories, Birmingham. Serum total cholesterol was measured by a modified Liebermann-Burchard method on a Technicon SMA 12/60 analyser. High density lipoprotein cholesterol was measured by the Liebermann-Burchard or enzymic procedures after precipitation with magnesium/phosphotungstate. ${ }^{6}$ The triglyceride estimations were carried out at the Royal Free Hospital School of Medicine using an enzymic method (Abbott Laboratories A-Gent triglycerides test). ${ }^{7}$ Triglyceride estimations were introduced after the survey had been completed in six towns and results are therefore available for 5675 men from the last 18 towns.

In some groups the totals for the three lipids differ because of missing data. The correlation coefficients shown are significant at the $0.1 \%$ level, unless some other level is indicated. In the description of the relation between body mass index and each of the lipid variables, the subjects have been ranked in order of increasing body mass index and divided into 20 groups of equal size.
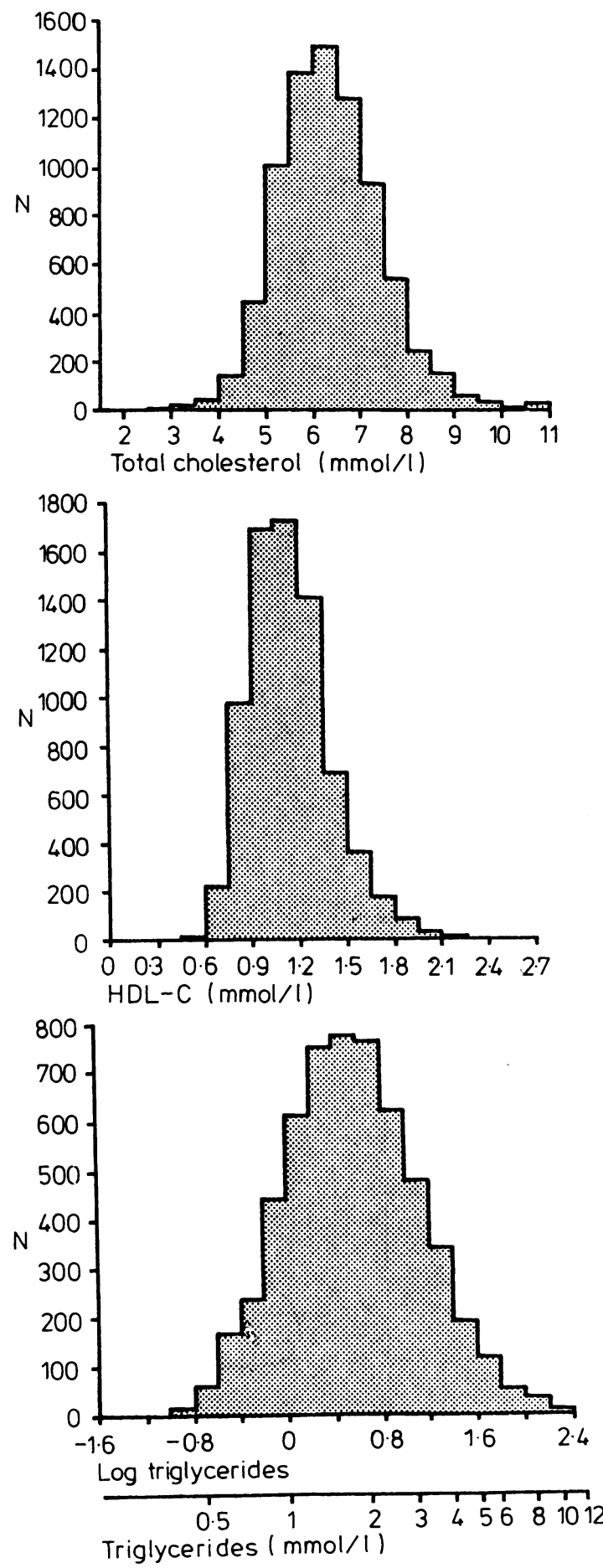

Fig. 1 The distribution of total cholesterol (7690), high density lipoprotein-cholesterol (7419), and log triglycerides (5675) in British men aged 40 to 59 years. 


\section{Results}

The distributions of the three lipid variables are shown in Fig. 1. Total cholesterol showed a normal distribution with a mean value of $6.30 \mathrm{mmol} / \mathrm{l}(242$ $\mathrm{mg} / \mathrm{dl}$ ). Of the men, $10 \%$ had total cholesterol levels above $7.7 \mathrm{mmol} / \mathrm{l}(296 \mathrm{mg} / \mathrm{dl})$. The distribution of HDL-cholesterol was slightly skewed to the right and that of triglycerides was very skewed to the right, which is reflected in the high standard deviation in relation to the mean (Table 1). In the statistical analysis we have therefore used logarithmic transfor- mations of HDL-cholesterol and triglycerides but in Tables 1 and 2 the arithmetic means are presented. The mean HDL-cholesterol level was $1 \cdot 15 \mathrm{mmol} / \mathrm{l}$ (44 $\mathrm{mg} / \mathrm{dl}$ ) and $10 \%$ of the men had HDL-cholesterol levels below $0.85 \mathrm{mmol} / \mathrm{l}(33 \mathrm{mg} / \mathrm{dl})$. The median value of the triglycerides was $1.71 \mathrm{mmol} / \mathrm{h}$ and $10 \%$ of the men had triglyceride levels above $3.65 \mathrm{mmol} / \mathrm{l}$.

\section{CORRELATION}

Total cholesterol and log triglycerides were positively correlated $\mathrm{r}=+0.37$.

Log HDL-cholesterol was inversely correlated with

Table 1 Mean total cholesterol, high density lipoprotein-cholesterol, and triglycerides in men aged 40 to 59 years according to age, body mass index, and other variables

\begin{tabular}{|c|c|c|c|c|}
\hline & No. & $\begin{array}{l}\text { Total cholesterol } \\
\text { (mmol/l) }\end{array}$ & $\begin{array}{l}\text { High density } \\
\text { lipoprotein-cholesterol } \\
\text { (mmol/l) }\end{array}$ & $\begin{array}{l}\text { Triglycerides } \\
\text { (mmol/l) }\end{array}$ \\
\hline $\begin{array}{l}\text { Age }(y) \\
40 \text { to } 44 \\
45 \text { to } 49 \\
50 \text { to } 55 \\
55 \text { to } 59\end{array}$ & $\begin{array}{l}1838 \\
1898 \\
1974 \\
2025\end{array}$ & $\begin{array}{l}6 \cdot 26 \\
6 \cdot 33 \\
6 \cdot 31 \\
6 \cdot 30\end{array}$ & $\begin{array}{l}1 \cdot 16 \\
1 \cdot 14 \\
1 \cdot 14 \\
1 \cdot 16\end{array}$ & $\begin{array}{l}2.05 \\
2.10 \\
2.05 \\
2.01\end{array}$ \\
\hline $\begin{array}{l}\text { Body mass index }(\mathrm{kg} / \mathrm{m} \\
<22.5 \\
22.5- \\
24.5 \\
26.5- \\
>28.5\end{array}$ & $\begin{array}{l}1255 \\
1766 \\
2047 \\
1421 \\
1243\end{array}$ & $\begin{array}{l}5.93 \\
6.22 \\
6.37 \\
6.46 \\
6.48\end{array}$ & $\begin{array}{l}1 \cdot 26 \\
1 \cdot 18 \\
1 \cdot 14 \\
1 \cdot 10 \\
1 \cdot 06\end{array}$ & $\begin{array}{l}1.47 \\
1.86 \\
2.07 \\
2.33 \\
2.55\end{array}$ \\
\hline $\begin{array}{l}\text { Alcohol consumption } \\
\text { None } \\
\text { Occasionally } \\
\text { Weekend } \\
1 \text { to } 2 \text { drinks } \\
3 \text { to } 6 \text { drinks } \\
>6 \text { drinks } \\
\text { Daily } \\
1 \text { to } 2 \text { drinks } \\
3 \text { to } 6 \text { drinks } \\
>6 \text { drinks }\end{array}$ & $\begin{array}{r}466 \\
1845 \\
725 \\
1234 \\
1095 \\
\\
585 \\
947 \\
832\end{array}$ & $\begin{array}{l}6 \cdot 21 \\
6 \cdot 27 \\
\\
6 \cdot 29 \\
6 \cdot 30 \\
6 \cdot 30 \\
\\
6.34 \\
6.39 \\
6 \cdot 27\end{array}$ & $\begin{array}{l}1.06 \\
1.08 \\
1.12 \\
1.13 \\
1.17 \\
1.19 \\
1.22 \\
1.26\end{array}$ & $\begin{array}{l}2.05 \\
2.01 \\
1.93 \\
2.04 \\
2.14 \\
1.96 \\
2.02 \\
2.21\end{array}$ \\
\hline $\begin{array}{l}\text { Cigarette smoking } \\
\text { Never } \\
\text { Ex-cig } \\
\text { Pipe/cig } \\
\text { Ex-cig/pipe/cigar } \\
\begin{array}{ll}\text { Cig: } & <20 \\
& 20 \\
& 21-39 \\
& >40\end{array}\end{array}$ & $\begin{array}{r}1624 \\
2108 \\
195 \\
607 \\
1188 \\
835 \\
846 \\
316\end{array}$ & $\begin{array}{l}6 \cdot 25 \\
6 \cdot 37 \\
6 \cdot 23 \\
6 \cdot 27 \\
6 \cdot 28 \\
6 \cdot 26 \\
6 \cdot 29 \\
6 \cdot 33\end{array}$ & $\begin{array}{l}1 \cdot 18 \\
1 \cdot 17 \\
1 \cdot 15 \\
1 \cdot 13 \\
1 \cdot 12 \\
1 \cdot 12 \\
1 \cdot 14 \\
1 \cdot 11\end{array}$ & $\begin{array}{l}1.92 \\
2.06 \\
2.00 \\
2.19 \\
2.11 \\
2.04 \\
2.02 \\
2.18\end{array}$ \\
\hline $\begin{array}{l}\text { Physical activity at wo } \\
\text { Low } \\
\text { Medium } \\
\text { High }\end{array}$ & $\begin{array}{r}3899 \\
2727 \\
777\end{array}$ & $\begin{array}{l}6.35 \\
6.26 \\
6.15\end{array}$ & $\begin{array}{l}1 \cdot 14 \\
1 \cdot 15 \\
1 \cdot 17\end{array}$ & $\begin{array}{l}2.06 \\
2.04 \\
2.03\end{array}$ \\
\hline $\begin{array}{l}\text { Social class } \\
\text { I } \\
\text { II } \\
\text { III non-manual } \\
\text { III manual } \\
\text { IV } \\
\text { V } \\
\text { Armed service }\end{array}$ & $\begin{array}{r}606 \\
1735 \\
720 \\
3326 \\
784 \\
318 \\
231\end{array}$ & $\begin{array}{l}6 \cdot 37 \\
6 \cdot 41 \\
6 \cdot 39 \\
6 \cdot 24 \\
6 \cdot 21 \\
6 \cdot 18 \\
6 \cdot 41\end{array}$ & $\begin{array}{l}1 \cdot 18 \\
1 \cdot 15 \\
1 \cdot 13 \\
1 \cdot 14 \\
1 \cdot 16 \\
1 \cdot 16 \\
1 \cdot 13\end{array}$ & $\begin{array}{l}1.91 \\
2.01 \\
2.10 \\
2.11 \\
1.98 \\
1.96 \\
2.12\end{array}$ \\
\hline $\begin{array}{l}\text { Mean } \\
\text { Standard deviation }\end{array}$ & & $\begin{array}{l}6 \cdot 30 \\
1.25\end{array}$ & $\begin{array}{l}1.15 \\
0.26\end{array}$ & $\begin{array}{l}2.05 \\
1.34\end{array}$ \\
\hline
\end{tabular}


$\log$ triglycerides $\mathrm{r}=-0.48$.

Log HDL-cholesterol and total cholesterol were not correlated $\mathrm{r}=-0.03$.

\section{PARTIAL CORRELATION}

All the three lipid variables were related to body weight and more specifically to body mass index. In order to assess to what extent the relation with body mass index could account for the interrelation of the three lipids, the simple correlation coefficients were again calculated after the effect of body mass index had been removed for each variable. These partial correlation coefficients, which were based on the residuals of the variables after controlling for body mass index were:

Total cholesterol and $\log$ triglycerides $r=+0.34$.

Log HDL-cholesterol and $\log$ triglycerides $r=-0.44$.

Log HDL-cholesterol and total cholesterol $\mathrm{r}=+0.002$.

All these coefficients are slightly lower than the simple correlation coefficients but remain of the same order of magnitude, indicating that body mass index is only to a very small extent a determinant of the interrelation between these lipids.

TOTAL CHOLESTEROL (Table 1 and Fig. 2)

There was a positive relation between body mass index and total cholesterol concentration $(r=+0 \cdot 17)$. While total cholesterol concentration increased moderately as body mass index increased, it only did so up to a body mass index of $28 \mathrm{~kg} / \mathrm{m}^{2}$. Beyond this there

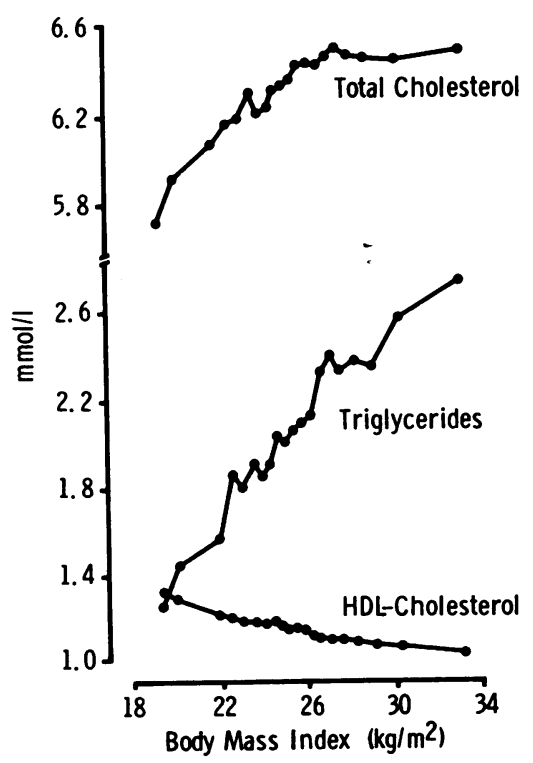

Fig. 2 The relation between body mass index (weight/height ${ }^{2}$ ) and total cholesterol, high density lipoprotein-cholesterol, and triglycerides (all in moll/l). was no further increase in mean total cholesterol concentration. About $20 \%$ of the men had a body mass index above this level, which corresponds to a man of $1.76 \mathrm{~m}$ and $87 \mathrm{~kg}\left(5^{\prime} 9^{\prime \prime}\right.$ and 13 stone $9 \mathrm{lb}$ ).

Men in the non-manual social classes (I, II, III nm) had higher mean total cholesterol levels than men in the manual classes (III $\mathrm{m}, \mathrm{IV}$, and V); the overall difference was $0.17 \mathrm{mmol} / /(\mathrm{p}<0.0001)$. The difference persisted even after adjustment for age, body mass index, and physical activity at work. This last variable was included in the analysis of covariance as there was a consistent downward trend in mean total cholesterol with increasing physical activity at work $(p<0.0001)$. Cigarette smoking appeared to have little effect on total cholesterol though ex-smokers had the highest mean level. As this effect could have been a result of their increased body mass index, an adjustment was made for the effect of body mass index, as well as for social class and physical activity at work. This brought the ex-smokers' mean total cholesterol down to the same adjusted level as the current smokers, and the main contribution to this adjustment came from the body mass index. The average increase in total cholesterol which can be ascribed to increased body mass index in ex-smokers is only about 0.04 $\mathrm{mmol} / \mathrm{l}$. Age and alcohol consumption had no influence on the total cholesterol level.

HDL-CHOLESTEROL (Table 1 and Fig. 2)

There was an inverse relation between HDLcholesterol and body mass index $(r=-0.25)$, with a $16 \%$ decrease from the lowest to the highest of the five body mass index groups. There was a positive relation between alcohol consumption and HDL-cholesterol which was dose related in both weekend and daily drinkers (Fig. 3). The mean levels of all the daily drinking groups were higher than those of the weekend drinking groups. The greatest increase was

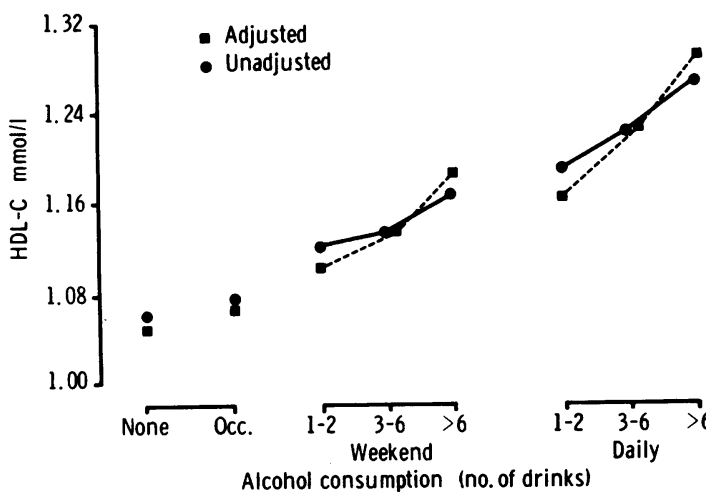

Fig. 3 High density lipoprotein-cholesterol and alcohol consumption adjusted and unadjusted for body mass index, cigarette smoking, and age. 
seen in the daily heavy drinkers, who were $16 \%$ higher $(0.19 \mathrm{mmol} / \mathrm{l})$ than occasional drinkers. Within the smoking categories, men who had never smoked or who were ex-smokers (that is, men not currently smoking at all) had the highest HDL-cholesterol levels. There was no clear relation with HDLcholesterol within the cigarette smoking categories though the lowest HDL-cholesterol level $(1 \cdot 11 \mathrm{mmol} /$ 1) was observed in those smoking more than 40 cigarettes a day. There was no social class pattern observed for HDL-cholesterol, no relation with age, and only a very slight trend $(p=0.06)$ towards higher concentration in men with the higher levels of physical activity at work.

HDL-CHOLESTEROL, SMOKING, AND ALCOHOL In order to examine further the relation between alcohol, smoking, and HDL-cholesterol, the HDLcholesterol levels in the eight smoking groups were tabulated against the eight drinking groups. Selected means from this cross-tabulation are presented (Table 2). The lowest concentrations of HDL-cholesterol are seen in those who drink occasionally or not at all. Within this group, cigarette smoking is associated with a lower mean HDL-cholesterol concentration than in those who have never smoked. In the never smoked group, heavy drinking on weekends or on a daily basis is associated with raised concentrations of HDL-cholesterol. In weekend heavy drinkers, the addition of cigarette smoking appears to inhibit this increase to a significant extent, whereas in daily heavy drinkers, the considerable increase in HDLcholesterol concentration is not affected by concurrent cigarette smoking. Thus, alcohol and smoking have opposing effects on HDL-cholesterol, with the effect of alcohol apparently being the overriding determinant.

A further exploration of the relation between HDL-cholesterol and alcohol intake was made, using analysis of covariance to adjust for the effects of smoking, body mass index, and age (Fig. 3). This adjustment produced a more conspicuous dose-response relation than initially observed in Table 1 , principally because heavier drinkers have a higher body mass index. Similar analyses were performed to examine

Table 2 Mean high density lipoprotein-cholesterol ( $\mathrm{mmol} / \mathrm{l})$ by alcohol consumption and smoking habits (number of men in parentheses)

\begin{tabular}{llll}
\hline $\begin{array}{l}\text { Alcohol } \\
\text { consumption }\end{array}$ & $\begin{array}{l}\text { None and } \\
\text { occasional }\end{array}$ & $\begin{array}{l}\text { Weekend }>6 \\
\text { drinks }\end{array}$ & $\begin{array}{l}\text { Daily }>6 \\
\text { drinks }\end{array}$ \\
\hline $\begin{array}{l}\text { Smoking habits } \\
\begin{array}{l}\text { Never smoked } \\
\text { Current cigarette } \\
\text { smoker }\end{array}\end{array}$ & $\begin{array}{l}1.12(566) \\
1.03(867)\end{array}$ & $\begin{array}{l}1.22(148) \\
1.14(561)\end{array}$ & \begin{tabular}{l}
$1.25(86)$ \\
\hline
\end{tabular} \\
\hline
\end{tabular}

the relation between HDL-cholesterol and body mass index, adjusting for age, smoking, and alcohol intake and also the relation between HDL-cholesterol and smoking, adjusting for age, body mass index, and alcohol intake. The effect of these adjustments was to suggest that the HDL-cholesterol relation with body mass index is virtually independent of age, smoking, and alcohol intake. After adjusting for age, body mass index, and alcohol consumption, the HDLcholesterol level in the non-smokers was increased, whereas it decreased in the current smokers, reflecting the positive relation between smoking and drinking habits.

\section{TRIGLYCERIDES}

There was a progressive and considerable increase in the triglyceride concentration with increasing body mass index, with a $73 \%$ increase from the lowest to the highest of the five body mass index groups in Table 1 . The relation appeared linear $(r=+0 \cdot 25$, Fig. 2). Triglyceride concentrations were associated with alcohol consumption, but not conspicuously (Table 1). Only those taking more than six drinks a day, either at weekends or daily, had higher mean concentrations than the occasional drinkers $(p<0.05)$. Age, cigarette smoking, social class, and physical activity at work showed no significant relation with triglycerides.

\section{Discussion}

The mean levels and distribution of the blood lipids vary widely between populations and, for some of the blood lipids, these inter-population differences appear to reflect the population differences in coronary heart disease mortality. ${ }^{18}$ Strong positive associations have been found between total cholesterol concentrations and the incidence of coronary heart disease, whereas the association with HDL-cholesterol concentration is strongly negative. ${ }^{2}$ These associations appear to be independent of other risk factors for coronary heart disease. There is uncertainty regarding the independence of the association between triglyceride concentrations and coronary heart disease incidence. ${ }^{9}$ Most of this information is derived from studies in the United States and there is little epidemiological information on blood lipids, their interrelations, and their associations with other variables for British populations. In an earlier paper we explored the question of inter-town comparisons of mean blood lipid concentrations and standardised mortality ratios. ${ }^{3}$ The Regional Heart Study provides background material for the overall coronary risk pattern in a random sample of middle-aged British men. The mean total cholesterol level in the men in this study is comparable with that observed in other populations with a 
high incidence of coronary heart disease, and is higher than the mean level currently observed in the United States. ${ }^{1}$ The mean HDL-cholesterol concentration is about the same as that observed in United States populations, resulting in a low mean HDLcholesterol/total cholesterol ratio, also suggesting a high risk for coronary heart disease. ${ }^{12}$ These comparisons between various studies make no allowance for differences between methods or possible secular changes and should be regarded with caution.

The use of non-fasting blood samples to assess the lipid concentrations must necessarily introduce an additional source of variation, that is the influence of recent food intake. The decision to use such samples in population surveys is based on feasibility and has precedents in other studies. ${ }^{1011}$ Serum total cholesterol concentration showed no diurnal variation over the 10 hour period in which blood samples were obtained. Both triglyceride and HDL-cholesterol concentrations showed diurnal variation, but no adjustment has been made for these variations in this paper. As the presentation is on a group basis and as adjustment is made for other variables wherever this is indicated, it is extremely unlikely that the diurnal variations in lipid concentrations introduce any systematic bias. When the data are used for incidence studies, in which individuals and small groups of subjects are involved, adjustments will be necessary and will be made. The predictive value of non-fasting triglycerides remains to be determined, and it has been suggested that postprandial measurements may be more relevant to the risk of coronary heart disease than the fasting levels. ${ }^{12}$

The contribution to the risk for coronary heart disease from each blood lipid variable considered separately and in combination will be of particular interest in the description of high risk subjects and in the planning of preventive measures. It is probable that total cholesterol and HDL-cholesterol contribute independently to the coronary heart disease risk, ${ }^{13}$ whereas the importance of non-fasting triglycerides may be overshadowed by their relation with cholesterol and HDL-cholesterol. ${ }^{9}$ The dynamic interrelation which seems to exist between HDL-cholesterol and triglycerides, however (that is the removal of triglycerides being dependent on the fasting HDLcholesterol level ${ }^{14}$ ) may itself be a determinant for atherosclerosis. Incidence data from the regional heart study may provide an answer to this possibility.

\section{AGE}

In most cross-sectional population studies of blood lipid concentration, mean total cholesterol increases with age, the main increase usually taking place from the second to the fifth decades. ${ }^{15^{-17}}$ The rate of increase in mean concentration varies considerably
Thelle, Shaper, Whitehead, Bullock, Ashby, Patel $\stackrel{\square}{\Phi}$

between populations and in some populations no $\stackrel{?}{\stackrel{c}{c}}$ age-related increase is observed. ${ }^{18}$ This variation in $\vec{F}$ relation is probably more the result of environmental $\stackrel{P}{\rightarrow}$ factors, diet in particular, than of some inherent

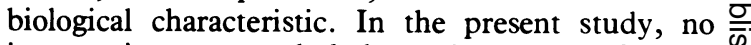
increase in mean total cholesterol was seen after the $\frac{\vec{\sigma}}{\overrightarrow{0}}$ age of 45, implying that the main increment in serum $\bigcirc$ cholesterol concentration had already taken place. क Consequently, this population can be regarded as hav- $\overrightarrow{0}$ ing been exposed to a high concentration of total $\stackrel{-}{\vec{H}}$ cholesterol for a longer period of life than populations $\vec{\omega}$ that continue to rise during the fifth or sixth decade. As this is a cross-sectional survey, the inferences we can drą about the effects of increasing age are very limited. The lack of increase in mean total cholesterol $\dot{\omega}$ concentration after 45 years, however, is not $\stackrel{\circ}{0}$ explained by changes in body mass index; age and $\mathcal{O}$ body mass index show no important relation in these $\frac{}{5}$ men. It is also highly unlikely to be produced by selective elimination from coronary heart disease of those with above average concentrations of total $\stackrel{3}{S}$ cholesterol, as the numbers involved below the age of 60 years are not likely to affect mean levels in groups of this size.

BODY MASS INDEX

The relation between body mass index and the lipid fractions has been well documented, 1920 but the mechanisms underlying these relations remain $\stackrel{\square}{\unrhd}$ unclear. In the present study, analysis of covariance $\overrightarrow{\overrightarrow{0}}$ has been used to adjust for the effects of age, smok- $\frac{3}{3}$ ing, and alcohol intake and it is clear from this that body mass index has a strong independent effect on the HDL-cholesterol concentration. It has been suggested that the negative correlation between HDLcholesterol and triglyceride concentrations observed consistently in population surveys ${ }^{21}$ and confirmed in 3 this study could be explained by both the variables being dependent on body mass index. ${ }^{19}$ Our data, however, do not support this suggestion as there was virtually no change in the partial correlation coefficients between triglycerides and HDL- $\frac{D}{0}$ cholesterol after controlling for body mass index.

The pattern of the relation observed between body 0 o mass index and total cholesterol is of considerable $N$ interest and unlike that seen for body mass index and triglycerides or body mass index and HDL- $\sigma$ cholesterol. The mean total cholesterol concentration rises with increasing body mass index until about $28 \stackrel{\circ}{\circ}$ $\mathrm{kg} / \mathrm{m}^{2}$, and then there is no further increase despite increasing body mass index. Neither social class nor physical activity at work had any influence on this relation. Few community studies of serum cholesterol $\overrightarrow{\mathbb{\Phi}}$ concentrations have examined the relation with body $\frac{\rho}{\mathbb{D}}$ mass index in any detailed manner. Most studies $\varrho$ report correlation coefficients, usually of very lowe 
order, ${ }^{22-24}$ or do not comment on the relation. The phenomenon we describe in Fig. 2, however, has been observed previously in a study of 7133 healthy London businessmen. ${ }^{25}$ In men aged 25 to 44 years the mean serum cholesterol rose with increasing relative weight. In men aged 45 to 64 years, serum cholesterol concentration increased to a relative weight of 110 to $119 \%$ and then showed no further increase in those with a relative weight of $120 \%$ or more. The pattern is very similar to that seen in our data. The crosssectional view of the relation between body mass index and blood lipids depicted in Fig. 2 should not be too readily interpreted in dynamic terms. It does focus attention, however, on the complexity of the effects associated with weight gain and weight loss.

The data could explain the early and distinct fall in triglycerides associated with weight loss and the difficulties encountered in reducing serum total cholesterol by weight reduction in the very obese subject. If so, weight reduction per se would be too nonspecific a recommendation if the main intention is to lower total cholesterol concentration in an individual or in a community, and more specific advice is indicated. ${ }^{26}$

\section{SOCIAL CLASS}

There was a small but significant difference between the mean total cholesterol concentration in the manual and non-manual workers. This is somewhat more pronounced if social classes I and II are compared with social classes IV and V. This finding of higher total cholesterol levels in the non-manual workers contrasts with other European surveys in which total cholesterol was lower in the higher social classes. ${ }^{27}$ The finding in our study was not explained by physical activity at work or by body mass index. The most likely explanation for this observed difference in mean total cholesterol concentrations is different dietary habits, but our data do not allow us to examine this in detail.

\section{CIGARETTE SMOKING AND ALCOHOL}

Both cigarette smoking and alcohol have been related to the risk of coronary heart disease. The effects of cigarette smoking are always positive, that is they increase the risk of coronary heart disease, while the reported effects of alcohol are conflicting. Light/ moderate drinking has been associated with lower blood pressures and less cardiovascular disease, ${ }^{28}$ and heavy drinking has been associated with higher blood pressures and with more ischaemic heart disease. ${ }^{29}$

Smoking and drinking are strongly correlated ${ }^{30}$ but appear to have opposing effects on some of the lipid fractions, making it extremely difficult to assess their independent contribution to coronary heart disease risk. Alcohol has been related to an increased HDL- cholesterol concentration in both clinical experiments and cross-sectional surveys. ${ }^{3132}$ The effect is independent of other factors such as body mass index and cigarette smoking and appears to have a dose-response relation. The higher levels of HDL-cholesterol in ex-smokers compared with the smoking groups is not the result of the ex-smokers drinking more. They have the same percentage of moderate/heavy drinking as light smokers and a lower percentage than moderate or heavy smokers. ${ }^{30}$ Even if cigarette smoking does decrease the HDL-cholesterol level, our study indicates that at relatively high levels of alcohol intake the effect of smoking on HDL-cholesterol is overwhelmed by the HDL-cholesterol-raising effect of alcohol (Table 2). If HDL-cholesterol is an important risk factor for coronary heart disease then the risk contribution from cigarette smoking, as determined by its effect on HDL-cholesterol, will be underestimated if alcohol consumption is not taken into account. The HDL-decreasing effect of cigarette smoking was modest but comparable with that observed in other studies. ${ }^{33}$ The actual difference increased slightly after adjusting for alcohol and body mass index but remained so small that it seems improbable that the HDL-decreasing effect of cigarette smoking is an important mechanism in coronary heart disease.

\section{Implications}

The aim of this presentation has been to describe the pattern of blood lipid concentrations in middle-aged British men and to examine a number of factors which might affect these patterns. It is evident that body mass index is closely associated with the concentrations of the blood lipids in these men, but the crosssectional nature of the data does not allow the full complexity of these associations to be explored. Almost certainly, the relations are neither direct nor simple, but are determined by a complex of dietary, physical activity, and constitutional factors. Therefore, one cannot assume from our findings that making a change in the body mass index will necessarily result in a change in the blood lipid concentrations in the same direction and to the same degree indicated by the cross-sectional data. The effect of weight reduction on blood lipids is likely to be determined by the manner in which the weight reduction is achieved, and in particular by the nature of the specific dietary regime involved. We should be prepared to test the relations we have shown in our attempts to reduce the risk of cardiovascular disease, but we should not expect the outcome of our endeavours to be readily predictable. The relations observed in this study will be explored more thoroughly when the incidence data are analysed, but in the meantime, they provide use- 
ful information which can be incorporated into our thinking about the determinants of coronary heart disease.

The British Regional Heart Study is supported by the Medical Research Council, and the Wolfson Research Laboratories by DHSS. The triglyceride estimations were carried out in the Department of Chemical Pathology, Royal Free Hospital School of Medicine under the direction of Dr D G Cramp. Dr Dag Thelle received a grant from the Norwegian Research Council for Science and the Humanities. We thank Mrs Mary Walker (research administrator) and Dr S J Pocock (statistician) for their contributions to this study.

\section{References}

1 Wynder EL, Blackburn H, Lewis B, Wissler R. Plasma lipids: optimal levels for health. (American Health Foundation, New York.) Academic Press, 1980.

2 Gordon T, Castelli WP, Hjortland MC, Kannel WB, Dawber TR. High density lipoprotein as a protective factor against coronary heart disease-The Framingham Study. Am F Med 1977; 62: 707-14.

3 Shaper AG, Pocock SJ, Walker M, Cohen NM, Wale CJ, Thomson AG. British Regional Heart Study: cardiovascular risk factors in middle-aged men in 24 towns. $\mathrm{Br}$ Med F 1981; 283: 179-86.

4 Great Britain Office of Population Censuses and Surveys. Classification of occupations. London: HMSO, 1970.

5 Morris JN, Crawford MD. Coronary heart disease and physical activity of work. Evidence of a national necropsy survey. $\mathrm{Br}$ Med ff 1958; ii: 1485-96.

6 Lopes-Virella MF, Stone P, Ellis S, Colwell JA. Cholesterol determination in high-density-lipoproteins separated by three different methods. Clin Chem 1977; 23: 882-4.

7 Eggstein M, Kreutz FH. Eine neue Bestimmung der Neutralfette im Blutserum und Gewebe. I Prinzip, Durchfuhrung + Besprechung der Methode. Klin Wochenschr 1966; 44: 262-7.

8 Rose G. Incubation period of coronary heart disease. $\mathrm{Br}$ Med f 1982; 284: 1600-1.

9 Hulley SB, Rosenman RH, Bawol RD, Brand RJ. Epidemiology as a guide to clinical decisions. The association between triglyceride and coronary heart disease. $N$ Engl f Med 1980; 302: 1383-9.

10 Leren P, Askevold EM, Foss OP, et al. The Oslo Study. Cardiovascular disease in middle-aged and young Oslo men. Acta Med Scand 1975; suppl 588: 5-38.

11 Bjartveit K, Foss OP, Gjervig T, Lund-Larsen PG. The Cardiovascular Disease Study in Norwegian Counties. Background and organisation. Acta Med Scand 1979; suppl 634: 1-70.

12 Zilversmit DB. Atherogenesis: a postprandial phenomenon. Circulation 1979; 60: 473-85.

13 Miller NE, Forde OH, Thelle DS, Mjos OD. The Tromsø Heart Study. High-density lipoprotein and coronary heart-disease: a prospective case-control study. Lancet 1977; i: 965-8.

14 Thelle DS, Cramp DG, Patel I, Walker M, Marr JW, Shaper AG. Total cholesterol, high density lipoproteincholesterol and triglycerides after a standardised high-fat meal. Human Nutrition: Clinical Nutrition 1982; 36C: 469-74.

15 Thelle DS, Forde OH, Try K, Lehmann EH. The Tromsø Heart Study: methods and main results of the cross-sectional study. Acta Med Scand 1976; 200: 10718.

16 Nicolaysen R, Westlund K. Group differences and age trend of serum cholesterol. Scand F Clin Lab Invest 1963; 15: 299-302.

17 Keys A, Mickelsen O, Miller EO, Hayes ER, Todd RL. The concentration of cholesterol in the blood serum of normal man and its relation to age. $\mathcal{F}$ Clin Invest 1950; 29: 1347-53.

18 Shaper AG, Jones KW. Serum cholesterol, diet, and coronary heart disease in Africans and Asians in Uganda. Lancet 1959, ii: 534-7.

19 Glueck CJ, Taylor HL, Jacobs D, Morrison JA, Beaglehole R, Williams OD. Plasma high-density lipoprotein cholesterol: association with measurements of body mass. The Lipid Research Clinics Program Prevalence Study. Circulation 1980; 62, suppl 4: 62-69.

20 National Mass Radiography Service, Health Services of Finnmark County, Ulleval Hospital, Faculty of Medicine, University of Tromso. The Cardiovascular Study in Finnmark 1974-1975. Nordic Council Arch Med Res 1979; Rep 25.

21 Davis CE, Gordon D, La Rosa J, Wood PD, Halperin M. Correlations of plasma high-density lipoprotein cholesterol levels with other plasma lipid and lipoprotein concentrations. The Lipid Research Clinics Program Prevalance Study. Circulation 1980; 62, suppl 4: 24-30.

22 Keys A. Seven countries. A multivariate analysis of death and coronary heart disease. Cambridge: Harvard University Press, 1980: 32.

23 Dawber TR. The Framingham Study. The epidemiology of atherosclerotic disease. Cambridge: Harvard University Press, 1980: 156.

24 Rifkind BM, Begg T. Relationship between relative body weight and serum lipid levels. $\mathrm{Br}$ Med F 1966; ii: 208-10.

25 Pincherle G. Factors affecting the mean serum cholesterol. I Chronic Dis 1971: 24: 289-97.

26 Shaper AG, Marr JW. Dietary recommendations for the community towards the postponement of coronary heart disease. $\mathrm{Br}$ Med $\mathcal{F}$ 1977; i: 867-71.

27 Holme I, Helgeland A, Hjermann I, Leren P, LundLarsen PG. Four-year mortality by some socioeconomic indicators: the Oslo study. $\mathcal{F}$ Epidemiol Community Health 1980; 34: 48-52.

28 Harburg E, Ozgoren F, Hawthorne VM, Schork MA. Community norms of alcohol usage and blood pressure: Tecumseh, Michigan. Am f Public Health 1980; 70: 813-20.

29 Dyer AR, Stamler J, Paul O, et al. Alcohol consumption, cardiovascular risk factors and mortality in two Chicago epidemiologic studies. Circulation 1977; 56: 1067-74.

30 Cummins RO, Shaper AG, Walker M, Wale CJ. Smok- ¿ ing and drinking by middle-aged British men: effects of $\underset{<}{\sigma}$ 楒 
social class and town of residence. $\mathrm{Br} M e d \mathcal{F}$ 1981; 283: 1497-502.

31 Belfrage P, Berg B, Hảgerstrand I, Nilsson-Ehle P, Tornqvist $\mathrm{H}$, Wiebe $\mathrm{T}$. Alterations of lipid metabolism in healthy volunteers during long-term ethanol intake. Eur $\mathcal{f}$ Clin Invest 1977; 7: 127-31.

32 Ernst N, Fisher M, Smith W, et al. The association of plasma high-density lipoprotein cholesterol with dietary intake and alcohol consumption. The Lipid Research Clinics Prevalence Study. Circulation 1980; 62, suppl 4: 41-52.
33 Criqui MH, Wallace RB, Heiss G, Mishkel M, Schonfeld G, Jones GTL. Cigarette smoking and plasma highdensity lipoprotein cholesterol. The Lipid Research Clinics Program Prevalence Study. Circulation 1980; 62, suppl 4: 70-6.

Requests for reprints to Professor A G Shaper, Department of Clinical Epidemiology and General Practice, Royal Free Hospital School of Medicine, London NW3 2PF. 